AL-TA'LIM JOURNAL, 23 (1), 2016, (10-21)
(Print ISSN 1410-7546 Online ISSN 2355-7893)
Available online at http://journal.tarbiyahiainib.ac.id/index.php/attalim

\title{
Intensive Class Training Model for Developing Lecturers'English Competence at IAIN Imam Bonjol Padang
}

\author{
Darmayenti*1 \\ Faculty of Adab and Humanities, State Institute for Islamic Studies \\ Imam Bonjol Padang,West Sumatera, Indonesia \\ 1'E-mail: darmayentid@yahoo.com \\ Nofel Nofiadri \\ Faculty of Adab and Humanities, State Institute for Islamic Studies \\ Imam Bonjol Padang,West Sumatera, Indonesia \\ E-mail: nofelnofiadri@yahoo.com
}

Received: 13 ${ }^{\text {th }}$ January 2016; Revised: 18 ${ }^{\text {th }}$ January 2016; Accepted: $28^{\text {th }}$ February 2016

\begin{abstract}
Research and Development (R\&D) project was used to develop lecturers' English competence particularly on speaking and writing at State Institute of Islamic Studies of Imam Bonjol Padang. The lecturers need to develop their competence in English in order to prepare themselves to add new information of lecturing materials and writing papers. Borg and Gall's steps were used to develop the model. Twenty active lecturers who had s2 and s3 program, who were randomly selected, participated on this research. During the process of the research, observation, questionnaire, and TOEFL test, speaking and writing tests were used to collect the data. The experimental research type and one group pre test- post test design were used to conduct the research. The result of the research showed that $74 \%$ of respondents need intensive class training model to develop their English competence. The implementation of intensive class training model gave a significant effect toward lecturers' English competence. It is concluded that this model is more effective to improve lecturers' on English competences. Therefore, it is recommended that this model can be implemented at IAIN Imam Bonjol Padang in order to develop lecturers' English competences and to enhance the quality of lecturers.
\end{abstract}

Keywords: Intensive class training model, English competence, lecturer

How to Cite: Darmayenti, D. (2016). Intensive Class Training Model for Developing Lecturers'English Competence at IAIN Imam Bonjol Padang. Al-Ta Lim Journal, 23(1).

doi: http://dx.doi.org/10.15548/jt.v23i1.163

Permalink/DOl:http://dx.doi.org/10.15548/jt.v23i1.163

\section{INTRODUCTION}

Lecturer is a professional educator at higher education whose duties are to develop and disseminate knowledge, through education, research and 
community service (Indonesia Law No 20/2003, and No 12/2012). It means that lecturer as a professional educator has the vision of the organization of learning in accordance with the principles of professionalism to meet the same rights for every citizen in obtaining quality education. They have to obtain competence in various fields including English competency. Lecturer competence determines the quality of the Tridharma implementation as indicated in the professional activities of lecturer.

Competence is a set of knowledge, skills and behaviors that must be owned, internalized and mastered by teachers or lecturers in carrying out the duties of professionalism (Law No 14/2005). It means that competence as an idealized capacity that is located as a psychological or mental property. One of the absolute competences controlled by the lecturer is competence in English. Language competence deals with the knowledge of the language and the ability to use that knowledge to interpret and produce meaningful text appropriate to the situation in which they are used (Hymes, 1972; Celce-Murcia, Dörnyei, \& Thurrell,1995). In short, competence involves knowing the language and performance involves doing something with the language. Language competence includes linguistics competence or grammatical competence, discourse competence, and sociolinguistics competence. Language competence is the best developed in the context of learning activities where language are used in real context.

To build these competencies are at least five components are interrelated to each other, namely: (1) language knowledge, the knowledge of the language that is relatively easy to master theoretically and studied autodidact; (2) cultural knowledge, the common language of cultural knowledge learned through sociolinguistics language; (3) context, namely the background (nonlinguistic) of substitutions or acts of communication; (4) language use, the use of language in context; (5) content knowledge, knowledge of the topic or theme being communicated (Brumfit \& Johnson, 1979). Each of these components has characteristics namely: (1) dynamic and interpersonal, (2) there is in any symbol system, (3) contextual, (4) involving basic skills, and (5) the relative (Troike, 2006). In addition, there are at least four levels of English competency owned by someone, namely: basic, intermediates, and Advanced (Kinginger \& Farrell, 2004).

Therefore, the development of competence of lecturers in English is as a policy for the institution. Improving English is used as a priority for several reasons. First, the demands of the main tasks of lecturers in teaching require a mastery of the English to update the information and disseminate it through seminars both nationally and internationally. Second, as academic communities at higher education, they have to write papers in English. So, the ability to use English becomes an essential part to publicize the findings and original ideas for the academic community, and required ability to read a variety of literature and readings presented in English. The implication is that the lecturers especially in IAIN Imam Bonjo/ Padang need to be equipped with English skills both oral and written.

The fact that was found in the field was the lack of a serious effort to develop the lecturers' English competence both institutional and faculty. Just a few lecturers wrote and attended an international seminar as speaker and writers in international journals. Language Development Centre of IAIN Imam Bonjol Padang just focuses on developing Arabic and English students' 
competences. However, developing lecturers' English competences has not been conducted yet. Based on the deep interview, almost all lecturers need to develop their English competence. Therefore, it is necessary to develop the appropriate model for developing lecturers' English competence.

The previous research which had been conducted stated that $74 \%$ of lecturers chose Intensive class training model to develop their competence in English (Darmayenti \& Nofiadri, 2014). One of the alternatives in developing competence in language that is through training (Dubois \& Rothwell,1996; 2004). Training is a process improvement knowledge and train of a person in order to improve performance on a task that is becoming responsibility or a job that is related to his work. Intensive course is as accelerated, time shortened, block format, compressed course, flexible, as well as alternative are courses in which the number of session or length of course, or class of time is shorter than usual format of the schedule (Scott \& Conrad, 1991; Scott, 2003). In addition, intensive means focused on one subject or are area for a short time; extremely thorough. Therefore, English training is an effort to develop the competence of lecturers in order to have the ability to be a professional in his duties either to develop or sharing knowledge. It is concluded that training is a way that can be used by someone to learn or improve their competence, including competence in English in short time. The previous research proved that intensive class gives significant effect toward students' English achievement (Nasiri \& Shokrpour, 2012; Mukundan, Mahvelati, \& Nimehchisalem, 2012; Al-Shumaimeri, 2013).
Based on the fact above, the purpose of this study were to design a model of the development of English competence and to find out the effect of intensive class training model toward lecturers' English competences, particularly on speaking and writing skills. This research is expected to contribute to improving the quality of lecturers IAIN Imam Bonjol Padang.

\section{METHOD}

This study was a research and development type (R\&D) which used to design the model of the development of lecturers' English competence at State Institute for Islamic Studies Imam Bonjol Padang. Research and development as the findings of research can be used to design new product (Borg \& Gall, 1983; 2003:569). In designing model, the activity should be started by doing need assessment. Therefore, there were some criteria should be analyzed. Model should (1) be oriented on lecturers' need; (2) be based competence, (3) be based on system approach, (4) be empirically tested (Fellows \& Liu, 2015). In addition, there were five stages in the training and development namely: (1) identify training needs / need assessment; (2) establish goals and objectives of training; (3) establishes the criteria of success by the means of measurement; (4) establish a training method; (5) conducting experiments and revision; and (6) to implement and evaluate (Mangkunegara \& Prabu, 2005).

There were six ways to be conducted namely, (1) determine the purpose of designing a model (2) gather information through reading the literature, observing the activities of lecturers in 
developing competence in English on campus, and analyzing the needs of the development of English competence; (3) design draft of a development model; (4) validate the model and revision; (5) implement the model; (6) and the last was evaluation of model. The new model was discussed with the experts through focus group discussion (FGD) at IAIN.

The data of this research were lecturers' achievement on English competences. Observation was used to search and collect all information from the lecturers in learning English. Questionnaire and interview were used to support the data collected. Twenty active lecturers in 2015 who had s2 and s3 program in IAIN Imam Bonjol Padang, who were randomly selected, participated on this research ((Sugiyono, 2010:120). One group pre test- post test design was used to conduct the research (Fraenkel, Wallen, \& Hyun, 1993). Speaking and writing tests were used to collect the data. Before and after giving treatment, the lecturers were given placement test, pre test and post test. Pre test and post test control group design was used as an experimental design (Creswell, 2009:313). Form of speaking was in question and answers (Finocchayro, 1983: 72; Brown, $2010: 201)$. The indicators were used to assess lecturers' speaking skill were pronunciation, vocabulary, grammar, fluency and comprehension (Brown, 2010). And form of writing test in essay writing. The indicators were used content, organization, vocabulary, language use, and mechanics (Spielberger, Jacobs, Russell, \& Crane, 1983).

There were two types of data analysis, qualitative and quantitative. Qualitative analysis was used to describe the result of implementation intensive class training model in developing English competence. Quantitative analysis was used to describe the effect model in improving lecturers' competence and analyze the gain score groups by using ttest. All the data were input into the computer, and then analyzed through the Statistical Package for Social Science (SPSS17.0). To be more specific, firstly, descriptive statistics such as frequencies means, and standard deviations were computed.

\section{RESEARCH FINDINGS AND DISCUSSION}

The finding of the research was found that the development of intensive class training model had four phases namely; preliminary analysis, analysis of input, process analysis and output analysis. The preliminary analysis was used to analyze the purpose of developing lecturer' English competence, lecturers' need on English competence, the strategies that mostly used by lecturers in developing English, and model that mostly was needed by lecturers to develop their English competence.

The result of preliminary analysis was found that lecturers at state Institute for Islamic Studies Imam Bonjo/ Padang had different strategies to develop their English language competences. $65 \%$ of lecturers tend to develop their listening competence through watching movie; $65 \%$ of them tend to develop their speaking competence through discussion with partners; $76 \%$ of them tend to develop their reading through looking up dictionary; $44 \%$ of them tend to develop their writing through sending short message via mobile (SMS). In addition, lecturers' competence in English through TOEFL test, the mean score was 406.63 maximum score was 483 and minimum score was 340 . However, speaking and writing competences were low. They just gained 55 for speaking and 77 for writing. $74 \%$ of lecturers need intensive class training model to develop their English 
competences.

The input analysis phase was an activity which contained four main things. Those were analysis of the participants to be trained, learning materials were used, the necessary facilities, and facilitators. Learning materials was designed in accordance with the level of competence which was owned by the participants. This material was taken from a variety of references relevant to the needs of competence development. Tutor or facilitator was needed to provide guidance in learning. Facilities were everything needed for learning such as rooms, learning media and other learning tools.

The analysis of the process phase was the main activity in the process of developing competence in English. At this stage, the activities were carried out planning, organizing, implementation and evaluation of activities. In the planning stage, the activities were carried out of the following steps. First, the identification of learning needs. It was included teaching material, and level of lecturers' English competence. Second, the activity was the identification of participants or lecturers. The participants were lecturers involved in training. The participants were divided into two levels through placement test, namely pre intermediate and intermediate levels. Thus, there would be obtained a description of the appropriate level of competence so that the material can be determined and appropriate learning model. Third, facilitators were guided the training. Facilitators were chosen based on his experience as a facilitator, as well as mastery of the English knowledge. Fourth, the identification of teaching materials used. The material focused on the competencies most needed by the lecturers were speaking and writing. The material for speaking focused on simple conversations and writing material focused on essay writing skills such as writing abstracts and papers.

At the stage of organizing the activities as follows. First, define the goals to be achieved, both general purpose and special purpose. Training objectives through intensive classes training in general were: (1) improve the mastery of English language competence; (2) developing the English language skills which included speaking and writing. The specific objective of organizing included: speaking and writing skills. Second, is the preparation of training materials, the result of intensive classroom training materials packed in accordance with the needs of intensive classroom training as contained in the special-purpose training. Third is the researcher's own training facilitator and assisted by expert lecturers under consideration mastery of the substance of the material, educational background in English. Fourth is the source of the cost of implementation. Fifth is the implementation schedule activities were developed and implemented based on an agreement between the participant and the researcher in charge.

The Implementation phase of intensive class training was being organized in such a way that the event was started with the opening of the activities by researchers. Implementation must be ensured that the participants were ready to learn. Researchers gave motivation in learning and explained each meeting learning objectives. The learning process should be explained in detail to participants included theory and activities. Learning activities performed using communicative learning model that 
included three stages, namely the pre activities, the main activities and post activities. First, on the preliminary activities, there were some activities carried out, namely (1) take attendance, (2) build participants' attention, (3) motivate participants and, greet them (4) provide guidance learning, (5) the give them pre test. Second, the main activities were carried out by the communicative learning techniques. Learning process should give full learning opportunity to participants. Technique performed was discussion, games, and role-play. On the post activity, the facilitator gave feedback of the learning process. Learning activities designed was equipped with the syllabus and teaching materials to be used. Evaluation phase training intensive class was activity to determine whether the participants got improvement or not after giving the training. There were two stages of the evaluation activities. First, the evaluation process of intensive class training and evaluation of training results. Second, the activity was obtaining the participants 'opinions by filling a questionnaire sheet to the training model implemented. The last phase was output analysis. The following was the recommendation models of Intensive class training model in developing lecturers' English competence at IAIN.
Figure1. Intensive Class Training Model for Developing Lecturers' English Competence at IAIN is Recommended

The implementation of intensive class training model gave significant influence on the English language competence of lecturers at IAIN Imam Bonjo/Padang especially on speaking and writing competences. It can be seen from the lecturers' scores on the following 
tables below:

Table 1. Data Description of Pre Test for both Two Groups

\begin{tabular}{|c|c|c|c|c|}
\hline \multirow{3}{*}{$\begin{array}{c}\text { Descrip } \\
\text { tion }\end{array}$} & \multicolumn{4}{|c|}{ Pre Test } \\
\hline & \multicolumn{2}{|c|}{$\begin{array}{l}\text { Intermediate } \\
\text { Group }\end{array}$} & \multicolumn{2}{|c|}{$\begin{array}{c}\text { Pre } \\
\text { Intermediate } \\
\text { Group }\end{array}$} \\
\hline & $\begin{array}{c}\text { Speak } \\
\text { ing }\end{array}$ & $\begin{array}{c}\text { Writi } \\
\text { ng }\end{array}$ & $\begin{array}{c}\text { Speaki } \\
\text { ng }\end{array}$ & $\begin{array}{c}\text { Writi } \\
\text { ng }\end{array}$ \\
\hline Resp & 10 & 10 & 10 & 10 \\
\hline Mean & 74.80 & $\begin{array}{c}73.6 \\
0\end{array}$ & 60,00 & $\begin{array}{c}63.9 \\
0\end{array}$ \\
\hline Median & 72.00 & $\begin{array}{c}79.5 \\
0\end{array}$ & 60.00 & $\begin{array}{c}62.0 \\
0\end{array}$ \\
\hline St. Dev & 3.795 & $\begin{array}{c}5.10 \\
3\end{array}$ & 3.266 & $\begin{array}{c}4.97 \\
7\end{array}$ \\
\hline Max & 80 & 85 & 64 & 70 \\
\hline Min & 72 & 70 & 56 & 56 \\
\hline Total & 748 & 786 & 600 & 639 \\
\hline
\end{tabular}

Table 2. Data Description of Post Test for both Two Groups

\begin{tabular}{l|c|c|c|c}
\hline \multirow{2}{*}{ Desc } & \multicolumn{4}{|c}{ Post Test } \\
\cline { 2 - 5 } & $\begin{array}{c}\text { Intermediate } \\
\text { Group }\end{array}$ & \multicolumn{2}{c}{$\begin{array}{c}\text { Pre } \\
\text { Intermediate } \\
\text { Group }\end{array}$} \\
\cline { 2 - 5 } & $\begin{array}{c}\text { Speak } \\
\text { ing }\end{array}$ & $\begin{array}{c}\text { Writi } \\
\text { ng }\end{array}$ & $\begin{array}{c}\text { Speaki } \\
\text { ng }\end{array}$ & $\begin{array}{c}\text { Writi } \\
\text { ng }\end{array}$ \\
\hline Resp & 10 & 10 & 10 & 10 \\
\hline Mean & 80.80 & 81.2 & 64.80 & 68.5 \\
\hline
\end{tabular}

\begin{tabular}{l|c|c|c|c}
\hline & & 0 & & 0 \\
\hline Median & 80.00 & $\begin{array}{c}82.5 \\
0\end{array}$ & 65.00 & $\begin{array}{c}70.5 \\
0\end{array}$ \\
\hline St. Dev & 3.795 & $\begin{array}{c}5.16 \\
0\end{array}$ & 4.917 & $\begin{array}{c}4.69 \\
6\end{array}$ \\
\hline Max & 84 & 87 & 72 & 74 \\
\hline Min & 72 & 72 & 56 & 62 \\
\hline Total & 788 & 812 & 648 & 685 \\
\hline
\end{tabular}

Table.3. Data Description before and after

\begin{tabular}{c|c|c|c|c}
\multicolumn{2}{c}{ Training } \\
\hline \multirow{2}{*}{$\begin{array}{c}\text { Treatm } \\
\text { ent }\end{array}$} & \multicolumn{2}{|c|}{$\begin{array}{c}\text { Intermediate } \\
\text { Group }\end{array}$} & \multicolumn{2}{c}{$\begin{array}{c}\text { Pre } \\
\text { Intermediate } \\
\text { Group }\end{array}$} \\
\cline { 2 - 5 } & $\begin{array}{c}\text { Speak } \\
\text { ing }\end{array}$ & $\begin{array}{c}\text { Writin } \\
\text { g }\end{array}$ & $\begin{array}{c}\text { Speak } \\
\text { ing }\end{array}$ & $\begin{array}{c}\text { Writi } \\
\text { ng }\end{array}$ \\
\hline Before & 74.80 & 73.60 & 60.00 & $\begin{array}{c}63.9 \\
0\end{array}$ \\
\hline After & 80.80 & 81.20 & 65.00 & $\begin{array}{c}70.5 \\
0\end{array}$ \\
\hline $\begin{array}{l}\text { Mean } \\
\text { Score }\end{array}$ & $5 \%$ & $8 \%$ & $5 \%$ & $6 \%$ \\
\hline
\end{tabular}

The table above could be explained that the result of intensive class training gave $5 \%$ improvement toward lecturers' competence on speaking and $8 \%$ for writing for 5 times treatments. The following table was the hypothesis testing.

Table 4. Hypothesis Testing of Intensive Class Training Model

\begin{tabular}{|c|c|c|c|c|c|}
\hline No & Resp & $\begin{array}{c}\text { Gain Mean } \\
\text { Score Speaking } \\
\text { Competence }\end{array}$ & $\begin{array}{c}\mathrm{t} \text {-test } \\
(\dot{a}=0,05)\end{array}$ & Findings & Conclusion \\
\hline 1 & Inter Group & 4.00 & $\begin{array}{l}\text { t-counted } \\
=4.743 \\
\text { t-table }=2.086 \\
p \text {-value }=0.00\end{array}$ & $\begin{array}{l}\mathrm{t} \text {-counted }>\mathrm{t}- \\
\text { table } \\
\mathrm{p} \text {-value } \quad 0,00 \\
<(\dot{\mathrm{a}}=0,05) \\
\mathrm{Ha}_{1} \text { accepted }\end{array}$ & $\begin{array}{l}\text { Intensive Class } \\
\text { Training Model } \\
\text { was better to } \\
\text { improve } \\
\text { lecturers' } \\
\text { speaking } \\
\text { English }\end{array}$ \\
\hline
\end{tabular}




\begin{tabular}{|c|c|c|c|c|c|}
\hline & & & & & competence \\
\hline 2 & Pre Inter & 4.60 & $\begin{array}{l}t \text {-counted }=3.146 \\
t \text {-table }=2.086 \\
p-\text {-value }=0.00\end{array}$ & $\begin{array}{l}\text { t-counted }>\text { t- } \\
\text { tabel } \\
\text { p-value } 0,00 \\
<(\text { á=0,05) } \\
\mathrm{Ha}_{1} \\
\text { accepted }\end{array}$ & $\begin{array}{l}\text { Intensive Class } \\
\text { Training Model } \\
\text { was better to } \\
\text { improve } \\
\text { lecturers' } \\
\text { speaking } \\
\text { English } \\
\text { competence }\end{array}$ \\
\hline No & $\begin{array}{l}\text { Respondent } \\
\mathrm{S}\end{array}$ & $\begin{array}{lr}\text { Gain } & \text { Mean } \\
\text { Score } & \text { on } \\
\text { Writing } & \text { English } \\
\text { Competence }\end{array}$ & $\begin{array}{l}\text { t-test } \\
(\dot{a}=0,05)\end{array}$ & Findings & Conclusion \\
\hline 1 & Inter & 2.60 & $\begin{array}{l}\text { t-counted } \\
=4.993 \\
\text { t-table }=2.086 \\
p \text {-value }=0,00\end{array}$ & $\begin{array}{l}\text { t-counted } \quad>t- \\
\text { tabel } \\
\text { p-value } \quad 0,00 \\
<(\dot{a}=0,05) \\
\mathrm{Ha}_{1} \text { accepted }\end{array}$ & $\begin{array}{l}\text { Intensive Class } \\
\text { Training Model } \\
\text { was better to } \\
\text { improve } \\
\text { lecturers' writing } \\
\text { English } \\
\text { competence }\end{array}$ \\
\hline 2 & Pre Inter & 4.60 & $\begin{array}{l}t \text {-counted }=5.059 \\
\text { t-table }=2.086 \\
p \text {-value }=0,00\end{array}$ & $\begin{array}{l}\text { t-counted }>\text { t- } \\
\text { tabel } \\
\text { p-value } \quad 0,00 \\
<(\dot{a}=0,05) \\
\mathrm{Ha}_{1} \text { accepted }\end{array}$ & $\begin{array}{l}\text { Intensive Class } \\
\text { Training Model } \\
\text { was better to } \\
\text { improve } \\
\text { lecturers' writing } \\
\text { English } \\
\text { competence }\end{array}$ \\
\hline
\end{tabular}

The table above showed that the first hypothesis was accepted for both two groups. The mean gain score of lecturers' achivement on speaking competency at Intermediate group were $(\bar{x}=4.00)$ and $(\bar{x}=4.60)$ for Pre Intermediate group. $\mathrm{t}_{\text {calculated }}=4.743$ and $p$-value in colom sig. (2-tailed) $=0.00$ for Intermediate group and $t_{\text {calculated }}=$ 3.146. The distribution score with the degree of freedom $\mathrm{t} \mathrm{dk} 9$ and ( $\mathrm{a}=0.05)$ was gained that $t_{t_{0.95(9)}}=4.743$. It can be stated that ${ }^{-}$calculated $\left(\mathrm{t}_{\text {calculated }}=4.743\right)>\mathrm{t}^{-}{ }_{\text {table }}(2.086)$ and p-value $(0.00)<a ́=0.05)$ for intermediate group and. The distribution score with the degree of freedom $t \mathrm{dk} 9$ and $(\alpha=0.05)$ was gained that $\mathrm{t}_{t}{ }_{0.95(9)}=3.146$. It can be stated that $\mathrm{t}$ - calculated $\left(\mathrm{t}_{\text {calculated }}=3.146\right)>\mathrm{t}_{\text {table }}(2.086)$ and

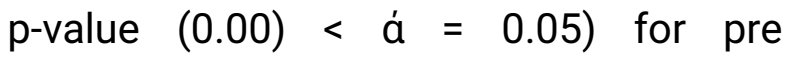
intermediate group.

The mean gain score of lecturers' achivement on writing competency at Intermediate group were $(\bar{x}=2.60)$ and $(\bar{x}=4.60)$ for Pre Intermediate group. $\mathrm{t}_{\text {calculated }}=4.993$ and $p$-value in colom sig. (2-tailed) $=0.00$ for Intermediate group and $t_{\text {calculated }}=5.059$. The distribution score with the degree of freedom $\mathrm{t} d \mathrm{k} 9$ and ( $\mathrm{a}=0.05$ ) was gained that $t_{t}{ }_{0.95(9)}=4.993$. It can be stated that $\mathrm{t}$ - calculated $\left(\mathrm{t}_{\text {calculated }}=\right.$ 4.993) > t- ${ }_{\text {table }}(2.086)$ and p-value (0.00) 
$<\dot{\mathrm{a}}=0.05)$ for intermediate group and. The distribution score with the degree of freedom t dk 9 and $(\dot{a}=0.05)$ was gained that $t_{t}$ 0.95(9) $=5.059$. It can be stated that ${ }^{t}$ calculated $\left(\mathrm{t}_{\text {calculated }}=\right.$ 5.059) $>t^{-}$table $(2.086)$ and p-value (0.00) $<\dot{\mathrm{a}}=0.05)$ for pre intermediate group. It could be concluded that there was a significant difference between the lecturers' speaking and writing competencies before and after training by using Intensive class training model.

The result of the research on lecturers' competence in English at State Institute for Islamic Studies Imam Bonjol Padang is found that they need to develop their competence in English. Mastering competence in English is one of lecturers' needs in order to gain information and knowledge that can be used for teaching and promoting research findings in international journals. English competence that the lecturers should be owned is communicative competence. It refers to the knowledge of the language and how they are able to use it. Communicative competence is made up four components that are comprised grammatical competence, discourse competence, socio-cultural competence, and strategic competence. Those components are essential and interrelated. (Hymes, 1972; Celce-Murcia et al., 1995; Savignon, 1997).

Many strategies have been conducted by lecturers as participants. The result of the research can be stated that most of participants tend to develop their listening competence through watching movie; they tend to do discussion with partners to develop their speaking; they develop their reading through looking up dictionary; they tend to develop their writing through sending short message via mobile (SMS). However, most of still have lack of competences on speaking and writing. These competences are very necessary for them to promote their paper whether is on seminar or writing on international journals. Most of them get difficulties to start to speak and to write although they have interesting ideas. Therefore, the development of competencies should be done with various efforts.

One of ways is to design a model that is appropriate and effective to use. In designing the model should be analyzed for the purpose of designing the model itself ((Fellows \& Liu, 2008). In determining the destination should consider to whom and for what the models are designed. Intensive Class Training Model is one model that has been able to increase the lecturers 'competence on English language at IAIN Imam Bonjol Padang. Intensive means a short-term learning intervention (Dubois \& Rothwell, 2004). It is intended to build individual knowledge, skill, and attitudes as work requirements.

Designing of intensive class training model has four phases namely; preliminary analysis, input analysis, analysis of process, and output analysis. First, Designing of that model is started from deep analysis of lecturers' need on English, English competence, and the strategies that are mostly used by lecturers in developing English. Second, input analysis contains four main activities, namely analysis of participants, learning materials, facilities, and facilitators. In designing learning materials is accordance with the level of competence which is owned by the participants. This material is taken from a variety of references relevant to the needs of competence development. Tutor 
or facilitator is needed to provide guidance in learning. Facilities are everything needed for learning such as rooms, learning media and other learning tools. Third, the main activity of this model is process of training. Fourth, the evaluation of English competence includes speaking and writing.

There are four activities carried out process of training. Those are planning, organizing, implementation and evaluation of activities. The activity has been done on planning are the identification of learning needs, identification of participants or lecturers who are involved, facilitators who guide the training, and teaching materials. The participants are divided into two levels through placement test, namely pre intermediate and intermediate levels. Thus, there would be obtained a description of the appropriate level of competence so that the material can be determined and appropriate learning model. Facilitators are chosen based on their experience as a facilitators, as well as mastery of the English knowledge. The material focused on the competencies most needed by the lecturers are speaking and writing. The material for speaking focused on simple conversations and writing material focused on essay writing skills such as writing abstracts and papers.

The activities have been conducted on organizing the training are to define the goals to be achieved both general purpose and special purpose of training preparation of training materials, facilitators, schedule and cost (Mangkunegara \& Prabu, 2005). The objectives of intensive classes training in general are to improve the mastery of English language competence and developing the English language skills which included speaking and writing. While, the specific objective of intensive class training are the lecturers able to use
English both spoken and written.

The Implementation of intensive class training is being organized in such a way that the event is started with the opening of the activities by researchers. Implementation must be ensured that the participants are ready to learn. Researchers give motivation in learning and explained each meeting learning objectives. The learning process should be explained in detail to participants included theory and activities. Learning activities performed using communicative learning model that includes three stages, namely the pre activities, the main activities and post activities.

First, the activities on the preliminary activities include take attendance, build participants' attention, motivate participants and, greet them, provide guidance learning, and give them pre test. Before conducting the training process, the facilitators do setting arrangement. Setting the seat in teaching process is conducted in order to make the students more active and more joy full (Harmer, 2001; McLeod, Fisher, \& Hoover, 2003).

Second, the main activities are carried out by the communicative learning techniques. Learning process should give full learning opportunity to participants. Communicative teaching techniques are used in training are discussion, games, and role-play. Role play is an unrehearsed dramatization in which individual improvise behaviors that illustrate acts expected of persons involved in defined situations (Killen, 2006). Doing role play, the participants can get variety of outcomes, including acquisition, of knowledge, application of knowledge, to develop further understanding and skills and attitudinal change. On the post activity, the facilitator gives feedback of the learning process. Learning activities 
design is equipped with the syllabus and teaching materials to be used. Evaluation phase training intensive class is activity to determine whether the participants got improvement or not after giving the training.

The result indicates that Intensive class training model has given improvement toward lecturers' English competence, including speaking and writing individually. In addition, intensive training can increase individual achievement in English (Nasiri \& Shokrpour, 2012; Mukundan, Mahvelati, \& Nimehchisalem, 2012). It is caused by the activities are carry out in training process. The activity has focused on to build individual competence. The activities are being carried out on training process have improved participants' fluency, vocabulary, pronunciation, grammar, and comprehension on speaking individually. During training process, almost all participants enjoy following the process. They are actively involved in speaking. Role play and discussion activities have made them active to promote themselves. In addition, intensive model also has improved participants' competence in writing. They are able to create essay into three or more paragraphs in correct sentences. They are able develop various topics of into an essay. However, this research has not analyzed the lecturers' motivation yet. Intensive class training can also improve someone motivation (Al -Shumaimeri, 2013)

So, it would be helpful if intensive class training model is adopted to gain the quality of lecturers at State Institute for Islamic Studies Imam Bonjo/Padang. It is one model that has improved lecturers' competence in English. It implies that IAIN as higher institution should give more change and attention to the lecturers to develop their competence including English competence.

\section{CONCLUSION AND RECOMMENDATIONS}

Based on the result of the study, It is concluded that developing lecturers' competence through intensive class training model has four main phases namely, preliminary analysis, analysis of input, process analysis and output analysis. On preliminary analysis, more than 74 percents of lecturers need to develop their competence in English through intensive class training model. The result of input analysis is that lecturers are divided into two groups, intermediate and pre intermediate groups. The result of process analysis is four activities should be done. Those are planning, organizing, implementation and evaluation.

The result of analysis is found out that the lecturers' competence in English has better improved weather on speaking and writing skills. Intensive class training model has proved that can improve lecturers' competence in English, speaking and writing, individually at State Institute for Islamic Studies (IAIN) Imam Bonjo/ Padang. It is concluded that this model is more effective to improve lecturers' on English competences. Therefore, it is recommended that this model as an alternative model can be implemented at IAIN /mam Bonjo/Padang in order to develop lecturers' English competences and to enhance the quality of lecturers. 


\section{REFERENCES}

Al-Shumaimeri, Y. (2013). The Effect of an Intensive English Language Program on First Year University Students' Motivation. Journal of Educational \& Psychological Sciences, 14(1), 11-32.

Borg, W. R \& Gall, M. D. (1983). Educational Research: An Introduction. New York: Longman Inc.

Borg, W. R., \& Gall, M. D. (1983). Educational research: An introduction. Retrieved from http://library.wur.nl/WebQuery/clc/ 215808.

Brumfit, C., \& Johnson, K. (1979). The communicative approach to language teaching. Oxford Univ Pr.

Canale, M. (1983). From Communicative Competence to Communicative Language pedagogy. In J. C. Richards, \& R. W. Schmidt (Eds.). Language and Communication. (pp. 2-27). London: Longman.

Celce-M. M., Dörnyei, Z., \& Thurrell, S. (1995). Communicative competence: A pedagogically motivated model with content specifications. Issues in Applied Linguistics, 6(2), 5-35.

Creswell, J. W. (2009). Research Design: Qualitative, Quantitative and Mixed Methods Approaches.third edition. Los Angeles: University of Nebraska-Lincoln Press.

Darmayenti \& Nofiadri. N (2014). Model Pengembangan Kompetensi Berbahasa Inggris Dosen di IAIN
Imam Bonjol Padang. Pusat Penelitian dan Pengembangan IAIN. DIPA 2014.

---. (2015). Efektifitas Pelatihan Model Kelas Intensif bagi Pengembangan Kompetensi Berbahasa Inggris Dosen. Pusat Penelitian dan Pengembangan IAIN. DIPA 2015.

Dubois, D. 1996. The Executive Guide to Competency-Based Performance Improvement. United Stated: HRD Press Harvest.

Dubois, D., \& Rothwell, W. (2004). Competency-based or a traditional approach to training? $T A N D D$, 58(4), 46-57.

Educational Testing Service (2001). Test of English as a Foreign Language. Princeton: ETS

Fraenkel. J. R. \& Norman E. W. (1990). How to Design and Evaluate Research. New York: McGraw-Hill Publishing Company.

Fraenkel, J. R., Wallen, N. E., \& Hyun, H. H. (1993). How to design and evaluate research in education (Vol. 7). McGraw-Hill New York. Retrieved from http://www.johnlpryor.com/JP_Dig ital_Portfolio/EDU_7901_files/EDU \%207901\%20Data\%20Definitions.p df

Gall, M. D., Gall J. P. \& Borg W. R. (2003).. Educational Research an Introduction. 7 th . ed. Boston: Pearson Education, Inc.

Hymes, D. (1972). On communicative competence. Sociolinguistics, 269293, 269-293. 
Indonesia, P. R. (2003). Undang-Undang Republik Indonesia Nomor 20 Tahun 2003 Tentang Sistem Pendidikan Nasional. Retrieved from http://eprints.dinus.ac.id/14666/1/ uu_20-2003_sisdiknas.pdf.

Killen, R. (2006). Effective Teaching Strategies: Lessons from Research and Practice. Cengage Learning Australia.

Kinginger, C., \& Farrell, K. (2004). Assessing Development of MetaPragmatic Awareness in Study Abroad. Frontiers: The Interdisciplinary Journal of Study Abroad, 10, 19-42.

Mangkunegara, A. P., \& Prabu, A. (2005). Evaluasi Kinerja Sumber Daya Manusia. Bandung: Aditama.

McLeod, J., Fisher, J., \& Hoover, G. (2003). The Key Elements of Classroom Management: Managing Time and Space, Student Behavior, and Instructional Strategies. ASCD.

Nasiri, E., \& Shokrpour, N. (2012). Comparison of intensive and nonintensive English courses and their effects on the student's performance in an EFL university context. European Scientific Journal, 8(8), 127-137

Savignon, S. J. (1997). Communicative competence: Theory and classroom practice. 2nd edition. New York: McGraw-Hill.

Sugiyono. (2010) Metode Penelitian
Pendidikan: Pendekatan Kuantitatif, Kualitatif, dan R\&D. Bandung: Alfabeta.
Scott, P. A. (2003). Attributes of highquality intensive courses. New Directions for Adult and Continuing Education, 2003(97), 29-38.

Scott, P. A., \& Conrad, C. F. (1991). A Critique of Intensive Courses and an Agenda for Research. Retrieved from http://eric.ed.gov/?id=ED337087.

Spielberger, C. D., Jacobs, G., Russell, S., \& Crane, R. S. (1983). Assessment of anger: The state-trait anger scale. Advances in Personality 
Assessment, 2, 159-187.

\section{Undang-Undang $R I$ Nomor 20 Tahun 2003 Tentang Sistem Pendidikan Nasional. Jakarta: BP.Cipta Jaya}

\section{Undang-Undang RI Nomor 14 Tahun} 2005 Tentang Guru dan Dosen. Jakarta: Sinar Grafika. 